\title{
The influence of hypothyroidism on liver regeneration: an experimental study in rats ${ }^{1}$
}

\author{
A influência do hipotireoidismo na regeneração hepatica: \\ estudo experimental em ratos
}

\author{
Maria de Lourdes Pessole Biondo-Simões ${ }^{2}$, Gustavo Rodrigues Alves Castro ${ }^{3}$, Guilherme Ramina Montibeller ${ }^{4}$, José \\ Augusto Sadowski ${ }^{4}$, Rachel Biondo-Simões ${ }^{5}$ \\ 1. Study performed at the Surgical Techniques and Experimental Surgery Program at the School of Medicine at Federal University of Paraná \\ (UFPR). Brazil. \\ 2. PhD. Associate Professor, Experimental Surgery, Department of Surgery at Universidade Federal do Paraná (UFPR) and Research \\ Methods at PUCPR \\ 3. Student, Scholarship National Council for Scientific and Technological Development (CNPq), Brazil \\ 4. Student, Scientific Initiation Program - UFPR. Brazil \\ 5. Student, Scientific Initation Program - PUCPR. Brazil
}

\begin{abstract}
Background: The influence of hypothyroidism in liver regeneration has been a controversial opinions. Purpose: The aim of this study is to identify the relationship between hypothyroidism and liver regeneration in rats. Methods: Forty male Wistar rats divided into two groups of 20 specimens each. One group (C) consisted of euthyroid rats, and the other (H) of hypothyroid rats. All the animals were anesthetized with xylazine and ketamine and subjected to a longitudinal incision in the anterior cervical region. The thyroid was completely resected in group $\mathrm{H}$ and left intact in group $\mathrm{C}$. Ten days after the first surgery, both groups of rats were weighed and submitted to partial hepatectomy, in which the left lateral and median lobes were resected and weighed. Examinations were carried out after 24 hours and, on day 7, using 3 methods: KWON et al.'s formula to identify increase in volume; mitotic figure count in five fields; and the percentage of PCNA-positive nuclei in five fields. Results: Using KWON's formula, the regeneration rate for Group C after 24 hours was 58.49\% whereas that for Group $\mathrm{H}$ was 50.42\% ( $\mathrm{p}=0.0165)$. After 7 days, the regeneration rate for Group C was 93.04\% and Group $\mathrm{H} 93.74 \%$ $(p=0.2165)$. The average number of mitotic figures after 24 hours was $14 \pm 1.5$ for Group C and $9.8 \pm 2.2$ for Group H $(\mathrm{p}=0,00016)$. After 7 days the corresponding figures were $5.4 \pm 1.1$ and $5.1 \pm 1.2(\mathrm{p}=0,6343)$. The average number of PCNApositive nuclei after 24 hours was $13.55 \pm 3.84$ in Group $C$ and $7.7 \pm 2.11$ in Group $\mathrm{H}(\mathrm{p}=0,0006)$ ). The corresponding figures after 7 days were $3.5 \pm 2.39$ for Group $\mathrm{C}$ and $4.11 \pm 1.90$ for Group $\mathrm{H}(\mathrm{p}>0.05)$. Conclusion: We conclude that hypothyroidism in rats causes a delay in hepatic regeneration in the first 24 hours, but that after seven days the rate of regeneration is equal to that in euthyroid rats.
\end{abstract}

Key words: 1. Liver. 2. Regeneration. 3. Hypothyroidism.

\section{RESUMO}

Background: A influência do hipotireoidismo na regeneração hepatica tem opiniões controvérsas. Objetivo: Identificar a relação entre o hipotireoidismo e a regeneração hepatica, em ratos. Métodos: Quarenta ratos Wistar, machos, divididos em dois grupos de 20 animais. Um grupo (C) constituído de ratos eutireoideanos e outro (H) de ratos hipotireoideanos. Todos os animais foram anestesiados com xilasina e quetamina e submetidos a uma incisão cervical longitudinal. A tireóide foi completamente ressecada no animais do grupo H e deixada intacta no grupo C. Dez dias após a primeira intervenção ambos os grupos de ratos foram pesados e submetidos à hepatectomia parcial, retirando-se os lobos lateral esquerdo e mediano, que foram pesados. Foram examinados com 24 horas e com 7 dias usando-se 3 métodos: formula de KWON et al. que identifica o aumento de volume; contagem de figures de mitose em cinco campos e de núcleos PCNA positivos em cinco campos. Resultos: Usando a formula de KWON et al. a taxa de regeneração do grupo C, após 24 horas, foi de $58.49 \%$ enquanto que a do grupo $\mathrm{H}$ foi de $50.42 \%$ ( $\mathrm{p}=0.0165$ ). Após 7 dias, a taxa de regeneração no grupo $\mathrm{C}$ foi de $93.04 \%$ e do grupo $\mathrm{H}$ 93.74\% ( $\mathrm{p}=0.2165)$. A média de figures de mitose após 24 horas foi de $14 \pm 1.5$ no grupo C e de $9.8 \pm 2.2$ no groupo $\mathrm{H}(\mathrm{p}=0,00016)$. Após 7 dias foi de $5.4 \pm 1.1$ e $5.1 \pm 1.2$ ( $\mathrm{p}=0,6343$ ). A média de núcleos PCA positivos, após 24 horas, foi de $13.55 \pm 3.84$ no grupo C e $7.7 \pm 2.11$ no grupo $\mathrm{H}(\mathrm{p}=0,0006)$ ). Com 7 dias foi de $3.5 \pm 2.39$ no groupo $\mathrm{C}$ e de $4.11 \pm 1.90$ for Group H ( $>0.05)$. Conclusão: Concluiu-se que o hipotireoidismo, em ratos, causa atraso da regeneração hepatica nas primeiras 24 horas, mas após 7 dias a regeneração se equivale à dos ratos eutireoideanos.

Descritores: 1. Fígado. 2. Regeneração. 3. Hipotireoidismo. 


\section{Introduction}

The liver's ability to regenerate itself has been known for thousands of years. Greek mythology tells of the punishment meted out to Prometheus. Because he discovered the secret of fire kept by the gods of Mount Olympus, he was punished by being chained to a rock, and each day an eagle fed off his liver, which regenerated itself during the night. Prometheus' punishment was thus never ending ${ }^{1}$. The liver's ability to regenerate itself in mammals is relatively unique. Only a few species, such as some worms, insects, reptiles and amphibians, can repair different parts of their bodies quickly through regeneration. In contrast, humans and large mammals exhibit limited regenerative ability. Some of the few organs and body parts that have an ability to regenerate to some extent include the liver, finger tips and peripheral nerves. Stem cells can provide a possible source of regenerative power. Among these types of reparative processes, liver regeneration stands out ${ }^{2}{ }_{<0007 \mathrm{D}}$ Liver regeneration is known to be a process involving highly organized and ordered tissue growth triggered by the loss of liver tissue. The process stops, for reasons that are unknown, when the liver volume is within 5 to $10 \%$ of its initial value. The same principles that govern liver regeneration following partial hepatectomy in rats apply to the growth response in a human liver transplanted to a new host. In this case a small transplant grows, but a large transplanted liver decreases in size. Thus, in each transplant, the optimal liver mass / body mass set point for the individual host is attained ${ }^{3}$. Hepatocytes are stable, highly differentiated cells of an epithelial nature that rarely divide. At any given time, about one in 20,000 hepatocytes is dividing, and each cell can divide once or twice at most. During liver regeneration, liver cells continue to perform crucial functions such as glucose regulation, synthesis of many blood proteins, secretion of bile and biodegration of toxic compounds required for homeostasis ${ }^{2}$. The kinetics of the regenerative response have already been well described in rats. DNA synthesis starts between 12 and 16 hours after partial hepatectomy and peaks between 24 and 26 hours. It is followed by a wave of mitoses, which starts between 22 and 24 hours after the partial hepatectomy and peaks between 32 and 34 hours. The regenerative process finishes within 7 to 14 days $^{1}$. In recent years, a great deal of new information concerning the events that may initiate liver regeneration has become available. It is only following several decades of research that the regulatory factors that trigger and/ or modulate the phenomenon of liver regeneration are beginning to be understood. These factors can be divided into the following three categories: (1) mitogenic agents or growth-stimulating factors capable of inducing synthesis of DNA and mitoses in a population of hepatocytes at rest (G0 phase) in culture mediums free of sera and any other mitogenic factors; (2) comitogenic agents, which do not have mitogenic effects by themselves and stimulate proliferation indirectly, potentiating the effect of mitogenic agents and reducing the effect of inhibiting agents; (3) inhibiting factors that are capable of inhibiting induced mitogenesis in primary hepatocyte cultures. There are also other factors that have been partially characterized. ${ }^{3}$ ss It is important that factors that accelerate liver regeneration be identified, as this reduces the period of liver insufficiency and thus makes larger resections and/or shorter recovery times possible. It is important to understand how and to what extent factors intrinsic to the patient's condition, such as hypothyroidism (subclinical or not), age and undernourishment, can influence regeneration and how mitogenic and comitogenic agents can be used to aid regeneration. Given that liver regeneration involves cell replication and intense metabolism, we believe that the thyroid gland is essential for this complex process to function properly. The thyroid synthesizes, stores and secretes $\mathrm{T} 3$ and $\mathrm{T} 4$. These hormones are responsible for increasing basal metabolism, heat production, blood flow and the supply of oxygen to and consumption of oxygen by tissues. They are also involved in other mechanisms associated with tissue response. Changes in T3 and T4 production are therefore probably directly related to failure of the processes involved in post-trauma and tissue-stress responses. Subclinical hypothyroidism is defined as the presence of biochemical evidence of thyroid-hormone deficiency in patients with little or no symptomatology of hypothyroidism. This condition is found in $26.4 \%$ of the elderly population according to Oliveira ${ }^{4}$. According to Schindler ${ }^{5}$ the incidence of thyroid disease in a population of postmenopausal women is as follows: clinical thyroid disease, about $2.4 \%$, subclinical thyroid disease, about 23.2\%. Hypothyroidism is probably one of the factors that may cause a poor response in liver transplantation and major surgery. The aim of this study is to identify the relationship between hypothyroidism and the degree of liver regeneration in rats as there is disagreement on this subject in the literature. Beyer ${ }^{6}$ reported that hypothyroidism induced in rats did not affect liver regeneration. However, studies carried out by Guerrieri et al $^{7}$ show important changes in regeneration in hypothyroid rats. Cervinková et $a l^{8}$ reached the same conclusion in a study in which rats treated with propylthiouracil (PTU) to induce hypothyroidism had lower liver-regeneration rates.

\section{Methods}

This study was carried out in compliance with the guidelines of the Brazilian Society for Animal Experimentation (COBEA) and Federal Law 6638. Forty male Wistar rats (Rattus norvegicus albinus, Rodentia mammalia) divided into two groups were used. One group consisted of 20 euthyroid rats (control C), and the 
other 20 hypothyroid rats $(\mathrm{H})$. All were approximately 140 days old and had an average weight of 380.36 \pm 24.34 g. The animals were kept in an animal colony with a light/dark cycle at room temperature and humidity and had unlimited access to water and commercial feed. After intramuscular anesthesia with xylazine and ketamine (0.1 mg of each component per $100 \mathrm{~g}$ of body weight), the animals from both groups were submitted to hair removal in the anterior cervical region and antisepsis with polyvinyl pyrrolidone-iodine. A longitudinal incision was then performed in the anterior cervical region, the median raphe opened and the trachea and thyroid identified. The thyroid was completely resected in Group $\mathrm{H}$ and left intact in Group C. Following a hemostasis check, the skin was joined with 5-0 nylon thread. For Group H, calcium was added to the drinking water to a final concentration of $2 \%$ for the remainder of the experiment ${ }^{9}$ in order to avoid hypocalcemia. Thirty days after the first surgery, the two groups were given intramuscular anesthesia with xylazine and ketamine again and weighed. After removal of hair from the ventral abdominal wall and antisepsis with pyrrolidone-iodine, a median laparotomy and partial hepatectomy were carried out, and the left lateral and median lobes were resected. This hepatectomy is equivalent to sectioning approximately $67 \%$ of the volume of the organ ${ }^{10}$. After checking hemostasis, laparorrhaphy was carried out. The resected segment was weighed and the value recorded in the protocol. During the partial hepatectomy, three rats in the control group and one in Group H died, leaving 17 rats in Group C and 19 in Group $\mathrm{H}$. During the postoperative period, the rats were kept under the conditions described above. When anesthetized again, they were weighed and submitted to relaparotomy; the first relaparotomy (after $24 \mathrm{~h}$ ) was carried out on ten rats from Group $\mathrm{H}$ and nine from Group $\mathrm{C}$, and the second (after seven days) was performed on nine rats from Group $\mathrm{H}$ and eight from Group C. The animals were killed. The resected parts were weighed and the results recorded in the protocol. The resected livers were then fixed in $10 \%$ buffered formalin and sent for histological examination. Slides were prepared with 4micrometer-thick cuts. These were stained with hematoxylin-eosin to evaluate the mitotic figure count, and PCNA-positive nuclei count was evaluated by immunohistochemistry using anti-PCNA antibody. Regeneration was assessed using three methods: by KWON et al.'s formula ${ }^{11}$ (1990), by the average number of mitotic figures in ten microscopic fields and by the average of PCNA-positive nuclei in five fields using immunohistochemistry.

Kwon et al.'s formula gives the regeneration rate based on weight.

$$
\%=\mathrm{D} / \mathrm{E} .100 \text { where } \mathrm{G}=\mathrm{R} / 0.7
$$

Where: $\mathrm{D}=$ liver weight per $100 \mathrm{~g}$ body weight on the day the animal was destroyed,

$\mathrm{E}=$ the estimated liver weight per $100 \mathrm{~g}$ of body weight before the hepatectomy and is calculated using the weight of the resected liver (R). G = estimated liver weight at the time of the hepatectomy.

\section{Results}

When evaluated using the KWON formula, liverregeneration rates in euthyroid rats and in hypothyroid rats were found to be different in the first 24 hours. At 24 hours the experimental group had an average liverregeneration rate of $50.42 \%$ compared with $58.36 \%$ in the control group $(p=0.0165)$. After one week, the liverregeneration rate in the control group and that in the experimental group were similar $(=0.2165)$ (Table 1 and Figure 1). When regeneration was assessed according to the average number of mitotic figures in ten fields, Group C was found to contain $14 \pm 1.5$ mitotic figures and Group H $9.8 \pm 2.2$ mitotic figures in 100 hepatocytes $(p=0,00016)$. After seven days Group C contained $5.4 \pm$ 1.1 mitotic figures and Group $\mathrm{H} 5.1 \pm 1.2$ mitotic figures in 100 hepatocytes ( $p=0,6343)$. The PCNA-positive nuclei count in five fields at 24 hours was $13.55 \pm 3.84$ in Group $\mathrm{C}$ and $7.7 \pm 2.11$ in Group $\mathrm{H}$; this difference was statistically significant $(\mathrm{p}=0,0006)$. After one week the corresponding figures were $3.5 \pm 2.39$ and $4.11 \pm 1.90$; this difference was not statistically significant $(\mathrm{p}>0.05)$ (Figure 2).

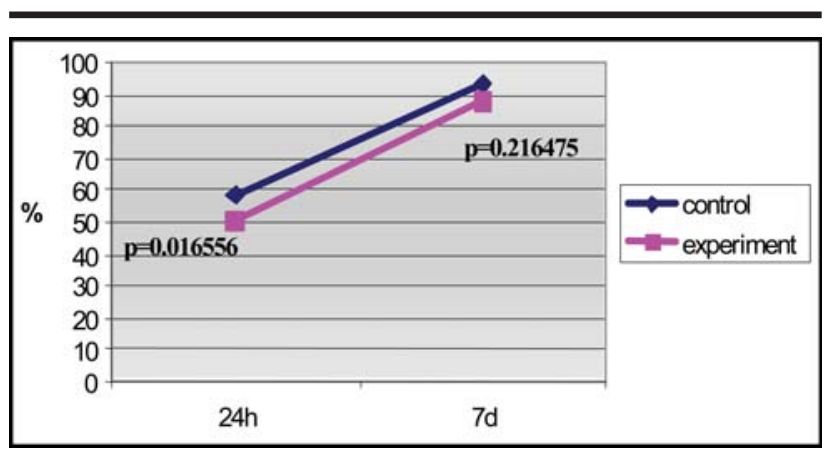

FIGURE 1 - Percentage increase in body mass calculated according to KWON's formula.

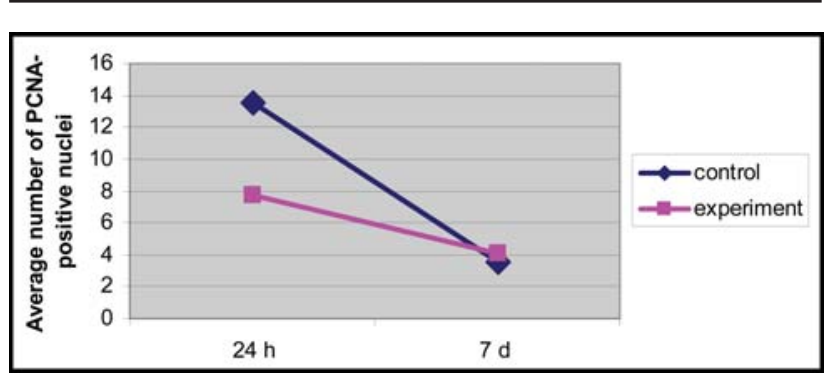

FIGURE 2 - Average number of PCNA-positive nuclei. 
TABLE 1 - Liver regeneration according to Kwon's formula

\begin{tabular}{lllll}
\hline & C.24h & E.24h & C.7d & E.7d \\
& 62.5 & 59.53 & 79.53 & 65.09 \\
& 46.11 & 40.01 & 84.61 & 77.53 \\
& 58.83 & 42.06 & 87.81 & 91.51 \\
& 65.63 & 57.5 & 92.75 & 94.12 \\
& 58.5 & 62.14 & 103.67 & 93.47 \\
& 56.77 & 51.58 & 118.25 & 101.46 \\
& 61.19 & 43.32 & 78.39 & 98.17 \\
& 54.2 & 60.2 & 99.29 & 79.6 \\
\hline Average & 61.53 & 42.21 & & $\mathbf{8 8 . 1 1 6 6 7}$ \\
\hline SD & & 45.66 & $\mathbf{9 3 . 0 3 7 5}$ & 11.65092 \\
Maximum & $\mathbf{5 8 . 3 6 2 2 2}$ & $5 \mathbf{5 0 . 4 2 1}$ & 13.53961 & 13.22 \\
Minimum & 5.680966 & 8.731808 & 14.55 & 101.46 \\
\hline 24-hour t test & 9.73 & 17.31 & 118.25 & 65.09 \\
7-day t test & 65.63 & 62.14 & 78.39 & \\
\hline
\end{tabular}

\section{Discussion}

The influence of hypothyroidism in liver regeneration has been a controversial issue. Beyer ${ }^{6}$ stated that, following five days of resection of approximately $70 \%$ of the liver volume in rats, the weight of the viscera was lower in animals with hypothyroidism but that the total content of hepatic DNA was similar in hypo and euthyroids. According to him, regeneration was practically normal. Meanwhile, Cervinková and Simek $^{8}$ reported inhibition of the DNA synthesis and mitotic activity. Poly(ADP-ribose) polymerase, a nuclear enzyme involved in DNA synthesis, in DNA repair, in cellular replication and transformation performs its role in the initial stages of liver regeneration induced by partial hepatectomy in rats. This activity is inhibited in rats with hypothyroidism. In the replication of hepatocytes, the thyroid hormone performs the regulating role of the poly(ADP-ribose) polymerase which reflects on the control of the nuclear protein involved in the DNA metabolism $^{12}$. Maliekal et $a^{13}$ observed in rats a lower synthesis of DNA following hepatectomy under hypothyroidism, a situation that improved with the injection of T3. According to them, the thyroid hormone can influence the DNA synthesis during liver regeneration and the activity of enzymes such as thymidine kinase is regular, which is important for DNA synthesis and, therefore, the division of cells. Although triiodothyronine (T3) is considered mitogenic for hepatocytes, Kariv et $a l^{14}$ did not observe this effect in vitro. They reported this fact in vivo and after liver resection. Their hypothesis was that the proliferation effect of the heptocytes seen with T3, should be indirect and induced by other cells in the liver that secreted mitogenic factors.
They described how in vitro stellate cells cultivated with T3 and IL.6 increase the secretion of the growth factor of the hepatocytes (HGF) after 48 hours. HGF is considered the most potent stimulator of the DNA synthesis in hepatocytes. It is produced by the Kupffer cells, Ito cells and the sinusoid endothelium, but not by the hepatocytes ${ }^{15}$. HGF has mitogenic and morphogenicaction in addition to anti-apoptotic ${ }^{15,16}$. Moro et $a{ }^{17}$ observed that in hypothyroid rats there is increased beta- 1 transforming growth factor (TGF-â, (45\%) and RNAm for the expression of the genes that negatively regulate hepatic growth (30\%). Thus, liver regeneration could be damaged in hypothyroidism. Malik et $a l^{18}$ reported that the administration of a single dose of $\mathrm{T} 3$ increased the regenerative capacity of the liver after hepatectomy and larger resections increased the survival rate of animals from $14 \%$ to $57 \%$. In this study, hypothyroidism in rats caused regenerative deficiency in the initial stages, demonstrated by the greater gain in mass $(p=0,016)$, lower number of mitosis figures per 1000 hepatocytes and the lower number of PCNA positive cells for each field $(p=0,0006)$. The results of this study show that hypothyroidism in rats causes a delay in early liver regeneration, i.e., regeneration in the first 24 hours. However, after one week the rate of regeneration in the hypothyroid rats increased and was equal to that of the euthyroid rats. There is controversy in the literature regarding this issue. The results of most of the studies that have been carried out are similar to those of the present study, although different methodologies were used. 


\section{Conclusion}

We conclude that hypothyroidism in rats influences liver regeneration and that early regeneration is delayed whereas late regeneration is unaffected.

\section{References}

1. Michalopoulos GK, DeFrances MC. Liver Regeneration. Science. 1997; 276(5309):60-6.

2. Su AL, Guidotti LG, Pezacki JP, Chisari FV, Schultz PG. Gene expression during the priming phase of liver regeneration after partial hepatectomy in mice. Proc Natl Acad Sci USA. 2002; 99(17):11181-6.

3. Fausto N. Liver regeneration. J Hepatol. 2000; 32(1 Suppl):19-31.

4. Oliveira ILC. Avaliação das funções tireóideas em idosos. [Tese-doutorado]. Salvador: Universidade Federal da Bahia; 1998.

5. Schindler AE. Thyroid function and postmenopause. Gynecol Endocrinol 2003; 17(1):79-85.

6. Beyer HS. Lack of effect of hypothyroidism on rat liver regeneration. Biochem Int. 1992; 27(3):497-500.

7. Guerrieri F, Nicoletti C, Adorisio E, Caraccio G, Leonetti $\mathrm{P}$, Zanotti F, Cantatore P. Correlation between decreased expression of mitochondrial F0F1-ATP synthase and low regenerating capability of the liver after partial hepatectomy in hypothyroid rats. J Bioenerg Biomembr. 2000; 32(2):183-91.

8. Cervinková Z, Simek J.Effect of propylthiouracil on liver regeneration in rats after partial hepatectomy. Physiol Res. 1992;41(2):141-6.

9. Waynforth HB, Flecknell PA. Experimental and surgical technique in the rat. $2^{\text {nd }}$ ed. London:Academic Press. 1992. p.31-2.
10. Higgins GM, Anderson RM. Experimental pathology of the liver. I. Restoration of the liver of the white rat following partial surgical removal. Arch Pathol. 1931; 12:186-202.

11. Kwon AH, Uetsuji S, Yamamura M, Hioki k, Yamamoto M. Effect of administration of fibronectin or aprotinin on liver regeneration after experimental hepatectomy. Ann Surg. 1990; 211(3):295-300.

12. Cesarone CF, Scarabelli L, Demori I, Balocco S, Fugassa E.Poly(ADP-ribose) polymerase is affected early by thyroid state during liver regeneration in rats. Am J Physiol Gastrointest Liver Physiol. 2000; 279(6):G1219-25.

13. Maliekal TT, Sudha B, Paulose CS. Kinetic parameters of Thymidine kinase and DNA synthesis during liver regeneration: role of thyroid hormones.Life Sci. 1997;60(21):1867-74.

14. Kariv R, Enden A, Zvibel I, Rosner G, Brill S, Shafritz DA, Halpem Z, Oren R. Triiodothyronine and interleukin-6 (IL-6) induce expression of HGF in an immortalized rat hepaticstellate cell line. Liver Int. 2003; 23(3);187-93.

15. Matsumoto K, Nakamura T. Hepatocyte growth factor: molecular structure, roles in liver regeneration, and other biological functions. Crit Rev Oncog. 1992; 3(12):27-54.

16. Kosai K, Matsumoto K, Funakoshi H, Nakamura T. Hepatocyte growth factor prevents endotoxin-induced lethal hepatic failure in mice. Hepatology. 1999; 30(1)151-9.

17. Moro L, Perlino E, Marra E, Greco M. Hepatocyte "priming"and increase in transforming growth factorbeta1 mRNA expression are delayed in hypothyroid versus euthyroid rats during liver regeneration. Int $\mathrm{J}$ Mol Med. 2006, 17(6);1063-8.

18. Malik R, mellor N, Selden C, Hodgson H. Triiodothyronine enhances the regenerative capacity of the liver following partial hepatectomy. Hepatology. 2003, 37(1);79-86.

\section{Correspondence:}

Maria de Lourdes Pessole Biondo-Simões

Rua Ari José Valle, 1987, Santa Felicidade

CEP 82030-000, Curitiba-Paraná - Brasil

Phone: (0XX41) 3297.4359

e-mail:biondo@avalon.sul.com.br
Conflict of interest: none Finantial source: none 